\title{
Ethyl Acetate Fraction of Caesalpinia sappan L. Enhances Cisplatin's Cytotoxicity on HeLa Cells via GI and S Arrest through p53 Expression
}

\author{
Ulfatul Husnaa ${ }^{1,2}$, Ni Putu Linda Laksmiani ${ }^{2,3}$, Ratna Asmah Susidarti ${ }^{2,4}$, \\ Edy Meiyanto ${ }^{2,4 *}$ \\ ${ }^{1}$ Master Course Program of Biotechnology, Graduate School, Universitas Gadjah Mada, Yogyakarta \\ ${ }^{2}$ Cancer Chemoprevention Research Center, Faculty of Pharmacy, Universitas Gadjah Mada, Yogyakarta \\ ${ }^{3}$ Department of Pharmacy, Faculty of Mathematics and Science, Universitas Udayana, Bali \\ ${ }^{4}$ Faculty of Pharmacy, Universitas Gadjah Mada, Yogyakarta
}

\begin{abstract}
Cisplatin (cisp) is the first line chemotherapeutic agent for several cancer diseases which can cause significant side effects and cellular resistance. Combination-chemotherapy treatment (cochemotherapy) was reported to be able to reduce cisp effects. Therefore, this study was carried out to investigate the cytotoxic activity of ethyl acetate fraction of $C$. sappan (EFC) in combination with cisp by observing apoptosis induction and cell cycle profile. Cytotoxic activity was evaluated by MTT assay. Cell cycle and apoptosis analysis were performed using flow cytometry and p53 expression was analyzed using immunocytochemistry. EFC performed cytotoxic effect on HeLa cells by showing morphological changes such as cell shrinkage, rounding and decreasing of cells viability in concentration dependent manner, giving $\mathrm{IC}_{50}$ value of $65 \mu \mathrm{g} / \mathrm{mL}$. Combination of EFC and cisp in low concentration decreased cell viability into $36.86 \%$. Further assay indicated that this combination caused redistribution of cell cycle arrest in $\mathrm{GI}$ and $\mathrm{S}$ phases through $\mathrm{p} 53$ stabilization in nucleus. However, that mechanism was not followed by apoptosis. These results provide evidence to support EFC development as the enhancer of cisp effect, by improving its cytotoxicity on HeLa cells. EFC increases HeLa cells sensitivity to cisp through $\mathrm{GI}$ and $\mathrm{S}$ cells' arrest depending on p53 expression.
\end{abstract}

Keywords: co-chemotherapy, EFC, cervix cancer HeLa cells, p53, GI and S arrest.

\section{INTRODUCTION}

Cervical cancer is the third most common disease among women worldwide (Jemal, et al., 2011), which $70 \%$ of its occurrence is caused by HPV infection (Castellsagué, 2008). Globally, 80$85 \%$ of death occurs in low- and middle-economicincome countries. The statistics estimation was made based on Globocan 2008 which state that the incidence of cervical cancer is increasing every year, with global estimation of new cases expected to increase $2 \%$ per annum to 770,000 new cases by 2030 (Forman, et al., 2012). There are several ways to treat cervical cancer, including surgery, radiation therapy, chemotherapy, and combination of those treatments. To date, chemotherapeutic agent is the most common treatment (Martin, et al., 2013; Leaver and Labonte, 2010).
Cisplatin (cisp) is the first chemotherapeutic agent from platinum (Jamieson and Lippard, 1999). This agent caused many side effects, such as severe nausea and vomiting, acute and chronic nephrotoxicity, anemia (Miller, et al., 2010; Rabik and Dolan, 2007), acute cochlear toxicity (ototoxicity) (Mukherjea and Rybak, 2011) and also developed cells resistance (Sirichanchuen, et al., 2012). Some of natural compounds were known as cytotoxic agent and can be combined with chemotherapeutic agent. Therefore, cisp's side effects and cellular resistance caused by cisplatin can be reduced using chemotherapeutic combination with natural agent by decreasing of cisplatin uses (Zhang, et al., 2011; Zhao, et al., 2004).

\footnotetext{
$\overline{\text { *Corresponding author e-mail : meiyan_e@ugm.ac.id }}$
} 
Herbal medicines used in nutrient supplements as anti-cancer and anti-inflammatory agents give benefit for patients (Ho, et al., 2002) to overcome side effects and drug resistance (Zhang, et al., 2011). The heartwood of Caesalpinia sappan has been used traditionally for medical treatment in Asia, consumed as a drink or a dye (Badami, et al., 2004). Previous studies showed that $C$. sappan extract (Ueda, et al., 2002) and its isolated compounds, brazilin and brazilein, potentially exhibited antitumor activity on several rodents and tumor cancer cells (Ren, et al., 2011; Yen, et al., 2011), but not on normal epithelial cells (Lee, et al., 2010). The main constituent of $C$. sappan, brazilin, can be oxidized by air and light to produce brazilein that is soluble in ethyl acetate (Kim, et al., 1997). Therefore, in this study, the effects of EFC-single treatment and in combination with cisp on $\mathrm{HeLa}$ cells were determined. Observation was done by observing cell viability, apoptosis induction, and cell cycle progression. Expression of p53 protein level was also investigated. More research in field of science will help for further explore the effectiveness and safety approaches, as both agents in conventional treatment and herbal medicine.

\section{METHODS}

\section{Preparation of EFC}

Caesalpinia sappan heartwood powder was obtained from Balai Besar Penelitian dan Pengembangan Tanaman Obat dan Obat Tradisional (B2P2TOOT), Tawangmangu, Indonesia. C. Sappan wood was extracted with methanol, evaporated, and partitioned with $n$-hexane and ethyl acetate by liquid-liquid extraction. Ethyl acetate fraction was evaporated by using rotary evaporator to get the residue as EFC. The dried fraction was re-solubilized in dimethyl sulfoxide (DMSO) before used as treatment sample. Cisplatin (Wako, $\geq 98 \%$ HPLC, Japan, CAS No.033-20091) was used as chemotherapeutic agent.

\section{Chemicals and reagents}

DMEM (Dulbecco's Modified Eagle Media, low glucose), FBS (Fetal Bovine Serum), penicillin/streptomycin, fungizone were purchased from Gibco (Invitrogen, USA). MTT (3-(4,5dimethylthiazol-2-yl)-2,5-diphenyltetrazolium bromide), PI (Propidium Iodide) (minimum 95\% (HPLC) were purchased from Sigma (Sigma-Aldrich Co., St. Louis, MO, USA). DMSO ( $99.5 \%$ pro GC, Sigma Aldrich Chemie GmBH, Steinheim, Germany), trypsin-EDTA (Gibco, Invitrogen, Canada), FITC-Annexin V Apoptosis Detection Kit (Biovision, USA), Triton-X (triton X-100 for GC, E.Merck, 64271, Darmstadt, Germany). SDS (Sodium Dodecyl Sulphate), $\mathrm{HCl}$ were purchased from Merck, Germany. RNase was obtained from Lab. Animal Sciences, NAIST, Japan. All other chemicals were used under analytical grade.

\section{Cell culture}

HeLa cells were obtained from Prof. Masashi Kawaichi, Laboratorium of Gene Function in Animal, Graduate School of Biological Science, Nara Institute of Science and Technology (NAIST), Japan. Cells were maintained in DMEM-low glucose, supplemented with $10 \%(\mathrm{v} / \mathrm{v}) \mathrm{FBS}, 1.5 \%$ $(\mathrm{v} / \mathrm{v})$ penicillin-streptomycin, and $0.5 \%(\mathrm{v} / \mathrm{v})$ fungizone. Cells were incubated at $37^{\circ} \mathrm{C}$ and $5 \%$ $\mathrm{CO}_{2}$.

\section{MTT assay}

HeLa Cells were grown $12 \times 10^{3}$ onto 96 -well plates before being exposured to drug treatment. For cell viability assay, cells were treated for $24 \mathrm{~h}$ with increasing concentration of EFC-single treatment $(0$, $30,40,50,60,70,80,90 \mu \mathrm{g} / \mathrm{mL})$. Combination treatment was done using both of EFC and cisp, incubated for $24 \mathrm{~h}$. As negative control, the cells were only treated with growth medium. At $100 \mu \mathrm{L}$ media containing MTT $(0.5 \mathrm{mg} / \mathrm{mL})$ was added to each well then incubated for $3 \mathrm{~h}$ at $37^{\circ} \mathrm{C}$. The reaction was stopped by dilution with $10 \%(\mathrm{w} / \mathrm{v})$ SDS in $0.01 \mathrm{M} \mathrm{HCl}$, then continued by incubation for overnight. The absorbance was determined by using ELISA reader (Bio-Rad microplate reader Benchmark, serial no. 11565 , Japan) at $\lambda 595 \mathrm{~nm}$ as previously described with some modification (Mosmann, 1983).

\section{Flow cytometry}

FACS analysis was carried out to investigate apoptosis quantification and cell cycle distribution. Around $5 \times 10^{5}$ cells/well were grown in 6-well plates and cells were treated with EFC, cisp, and combination of both compounds for $24 \mathrm{~h}$. 
Trypsinized adherent cells were collected and were prepared for detection. Cell apoptosis was detected by using a FITC-Annexin V Apoptosis Detection Kit (Biovision, USA). Then, apoptosis was analyzed by flow cytometry (BD FACS-Calibur, USA).

For cell cycle analysis, the trypsinized adherent cells were collected and detected by adding flow cytometry reagents $(25 \mu \mathrm{L} \mathrm{PI}, 2.5 \mu \mathrm{L}$ RNase, $0.5 \mu \mathrm{l}$ Triton-X in $500 \mu \mathrm{L}$ PBS), followed by incubation at room temperature for 10 minutes in the dark. The cell suspension was transferred into a flow cytometer tube and its cell cycle profile was read using flow cytometry. The cell cycle profile was analyzed by ModFit LT 3.0.

\section{Immunocytochemistry}

Immunocytochemistry was developed (Cozmei, et al., 2002) with some modifications. HeLa cells were grown with the density of $5 \times 10^{4}$ cells/cover slip in 24-well plate for $24 \mathrm{~h}$ prior to treatment of EFC, cisp, and combination of both. Cells were treated for $15 \mathrm{~h}$ and then fixed with cold methanol for 10 minutes and washed twice using PBS and sterile water. Cells were blocked with $\mathrm{H}_{2} \mathrm{O}_{2}$ and then pre-diluted blocking serum was added, continued with incubation for 10 minutes. Cells were washed using PBS and incubated with primary monoclonal antibody anti-p53 (mouse monoclonal anti-p53 antibody, BioGenex) overnight. Cells were washed using PBS, then universal detection kit was added (Star Trek Universal HRP Detection Kit, Ref STUHRP 700L10-KIT, Biocare Medical). Cells were then incubated with biotinylated universal secondary antibody for 20 minutes, followed by streptavidin-enzyme horse radish peroxidase for 10 minutes. Substrate solution chromogen 3,3'diaminobenzidine (DAB) was exposed for 10 minutes and cells were counterstained with Mayer's Haematoxylin (Dako) for 1 minute. Then, cells were fixed with ethanol and xylol. Between each immunostaining step, cells were washed briefly in PBS pH 7.4. Negative controls were prepared by replacing the primary antibody with PBS. The p53 expression on the cells was observed by binocular microscope (Nikon YS 100, Japan).

\section{Statistical analysis}

\section{Single and combinational cytotoxicity assay:}

$\mathrm{IC}_{50}$ value was calculated by equation $\mathrm{y}=\mathrm{Bx}+\mathrm{A}$ acquired from linear regression between concentration and $\%$ cell viability. $\mathrm{IC}_{50}$ is concentration inhibiting 50\% cell proliferation. Cell viability was calculated with the formula (Meiyanto, et al., 2011):

$$
\% \text { Cells viability }=\frac{\text { Treated cells abs }- \text { medium control abs }}{\text { Cells control abs }- \text { medium control abs }} \times 100 \%
$$

The datum were performed as average \pm SE from triplicate $(n=3)$ experiments.

Cell viability and p53 expression were statistically analyzed using one way ANOVA and statistical significance was estimated by using Tukey HSD. Statistical significance was determined at $p<0.05$.

\section{RESULT}

\section{Cytotoxic EFC and Its Combination with Cisp on HeLa cells}

Cytotoxicity assay was used to evaluate the potential of EFC cytotoxicity on HeLa cells. Furthermore, $\mathrm{IC}_{50}$ value was acquired as the parameter of EFC concentration to inhibit $50 \% \mathrm{HeLa}$ cells' growth. Fig. 1 shows the effect of EFC to cell viability for $24 \mathrm{~h}$ treatment. EFC caused inhibition on cell growth in a concentration-dependent manner (Fig. 1A). We suggest that EFC was found to be cytotoxic on HeLa cells with $\mathrm{IC}_{50}$ value of $65 \pm 1.5$ $\mu \mathrm{g} / \mathrm{mL}$. This fraction exhibited potent cytotoxicity $\left(\mathrm{IC}_{50} \leq 100 \mu \mathrm{g} / \mathrm{ml}\right.$ ) (Prayong, et al., 2008). Treated cells showed cytotoxic effect with changes in cell morphology and the decrease of cell viability. Viable cells exhibited epithelial shape, but after being treated with certain concentration of samples, the cells exhibited cell shrinkage and rounding (Fig. 1B).

Cisp performed cytotoxic activity on HeLa cells with $\mathrm{IC}_{50}$ value of $16 \mu \mathrm{M}$ (data not showed). $\mathrm{IC}_{50}$ value was then used to determine the concentration in combinational treatment that is concentration lower than $\mathrm{IC}_{50}$ value. Various 
concentrations of cisp $(2,4,8 \mu \mathrm{M})$ were combined with $28 \mu \mathrm{g} / \mathrm{mL}$ EFC. Fig. 2 sections confirm that combinational treatment performed morphological changes and caused decrease of the cells number. Cell viability measurement of the combination group (EFC combined to cisp) was considered significantly different compared to cisp-single treatment group $(p<0.05)$. At $8 \mu \mathrm{M}$ cisp in combination with 28 $\mu \mathrm{g} / \mathrm{mL}$ EFC decreased significantly HeLa cells' viability compared to 2 and $4 \mu \mathrm{M}$ cisp $(p<0.05)$.
There was approximately 63\% decrease in $\mathrm{HeLa}$ cells' viability treated by $28 \mu \mathrm{g} / \mathrm{mL}$ EFC combined 8 $\mu \mathrm{M}$ cisp for $24 \mathrm{~h}$. Cell viability acquired from single treatment of EFC and cisp above $100 \%$ was considered as $100 \%$. Therefore, both lowconcentration of EFC and cisp showed no inhibitory effect on HeLa cells. Whereas, combination between EFC and cisp caused a significant decrease in cell viability. This result indicates that EFC can be used in combination with cisp on HeLa cells.

(A)

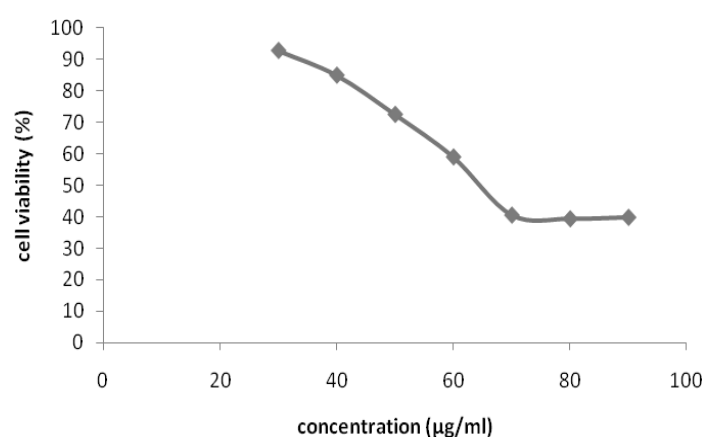

(B)

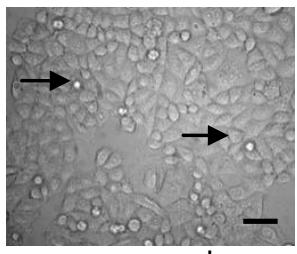

control

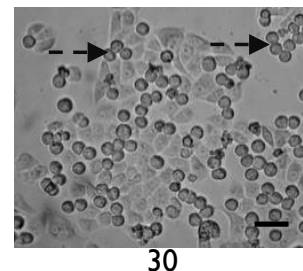

30

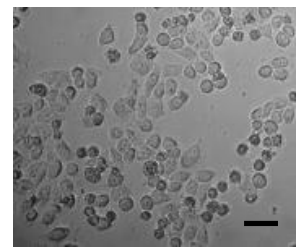

60

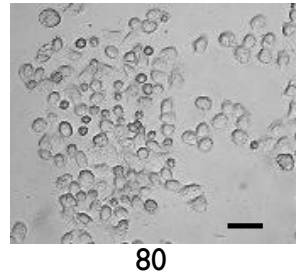

$\mathrm{EFC}(\mu \mathrm{g} / \mathrm{mL})$

Figure I. Effects of EFC on cell viability and morphological changes on HeLa cells. (A) HeLa cells was treated using EFC (0,30$90 \mu \mathrm{g} / \mathrm{mL}$ ) for $24 \mathrm{~h}$ and determined by MTT assay as described in materials and methods. Data are representative of values from three independent experiments. (B) Morphological changes of HeLa cells were observed using binocular microscope. Viable cells (full arrow), morphological changes (dotted line), bars: $50 \mu M$ (magnification I00x) 
(A)

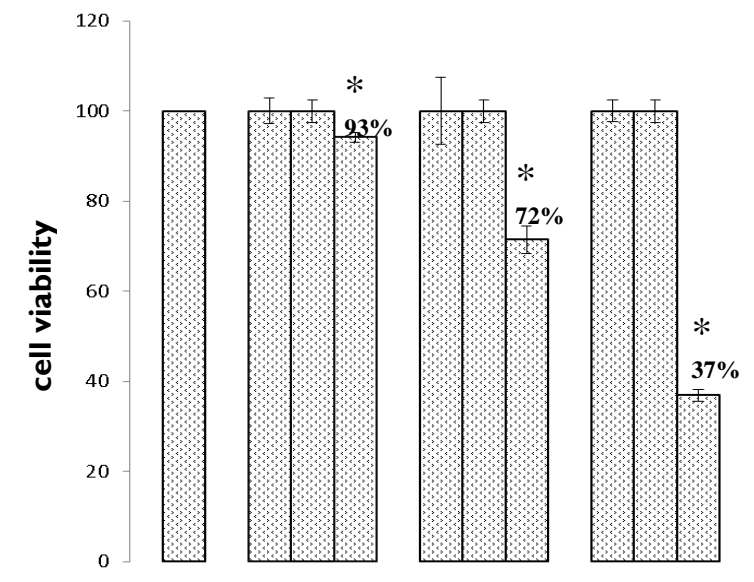

\begin{tabular}{|c|c|c|c|c|c|c|c|c|c|c|}
\hline Cisp $2 \mu \mathrm{M}$ & - & + & - & + & - & - & - & - & - & - \\
\hline Cisp $4 \mu \mathrm{M}$ & - & - & - & - & + & - & + & - & - & - \\
\hline Cisp $8 \mu \mathrm{M}$ & - & - & - & - & - & - & - & + & - & + \\
\hline $\mathrm{EFC} 28 \mu \mathrm{g} / \mathrm{ml}$ & - & - & + & + & - & + & + & - & + & + \\
\hline
\end{tabular}

(B)

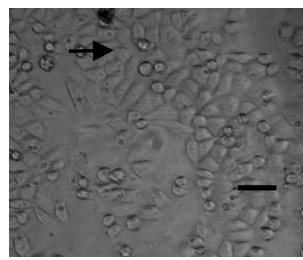

control

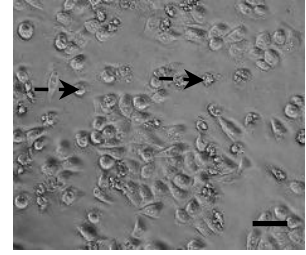

$2 \mu \mathrm{M}$ cisp

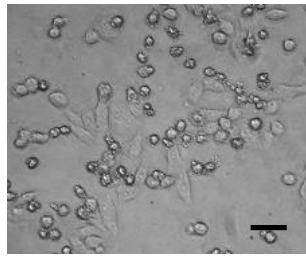

$4 \mu \mathrm{M}$ cisp

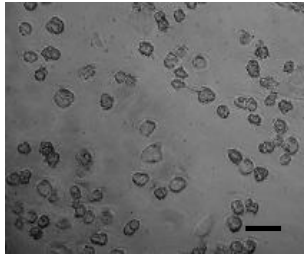

$8 \mu \mathrm{M}$ cisp

$28 \mu \mathrm{g} / \mathrm{mL}$ EFC

Figure 2. Cytotoxic Effect of EFC was combined with cisp on HeLa cells. (A) HeLa cells were treated for $24 \mathrm{~h}$ with combination both of EFC and cisp caused decreasing percentage of cell viability. Cells viability were determined by MTT assay as described in materials and methods. (*) Significances $(p<0.05)$. (B) Cells' morphological changes treated with combination both of EFC $28 \mu \mathrm{g} / \mathrm{ml}$ and cisp $(2,4,8 \mu \mathrm{M})$ were examined and photographed by binocular microscope. Viable cells (full arrow), morphological changes (dotted line), bars: $50 \mu \mathrm{M}$ (magnification 100x).

\section{Effect of EFC and Cisp on Cells Death Induction on HeLa Cells}

According to the cytotoxic combination between EFC and cisp mentioned below, cell death detection was carried out by flow cytometry using the less of $\mathrm{IC}_{50}$ concentration. Fig. 3 shows the effect of EFC, cisp and combination of both caused cell death induction. EFC could not increase cell death through apoptosis signal. However, it could increase necrosis cell death which was induced by combination of EFC and cisp compared to cispsingle treatment. Cisp-single treatment and combination of cisp with EFC ( $24 \mathrm{~h}$ treatment) caused $82 \%$ and $72 \%$ cell death, respectively (Fig. 3B). The apoptosis value of cisp-single treatment and its combination with $\mathrm{EFC}$ were $71.50 \%$ and $40.41 \%$, while the necrosis values were $10.38 \%$ and $31.81 \%$, respectively. EFC-single treatment caused less cell death induction with apoptosis value of $5.85 \%$ and necrosis value of $2.38 \%$. These results suggest that EFC may affect HeLa cells' sensitivity to cisp which is caused by apoptosis and necrosis cell death. 
(A)

control

$20 \mu \mathrm{g} / \mathrm{mL}$ EFC

$8 \mu \mathrm{M}$ Cisp

$20 \mu \mathrm{g} / \mathrm{mLEFC}+$
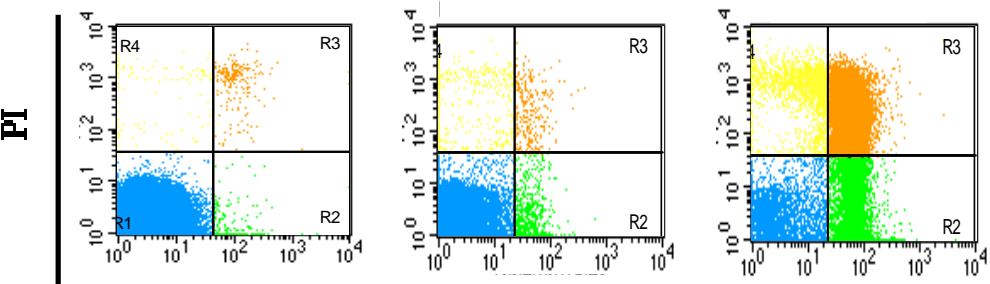

$8 \mu \mathrm{M}$ Cisp

Annexin V-FITC

(B)
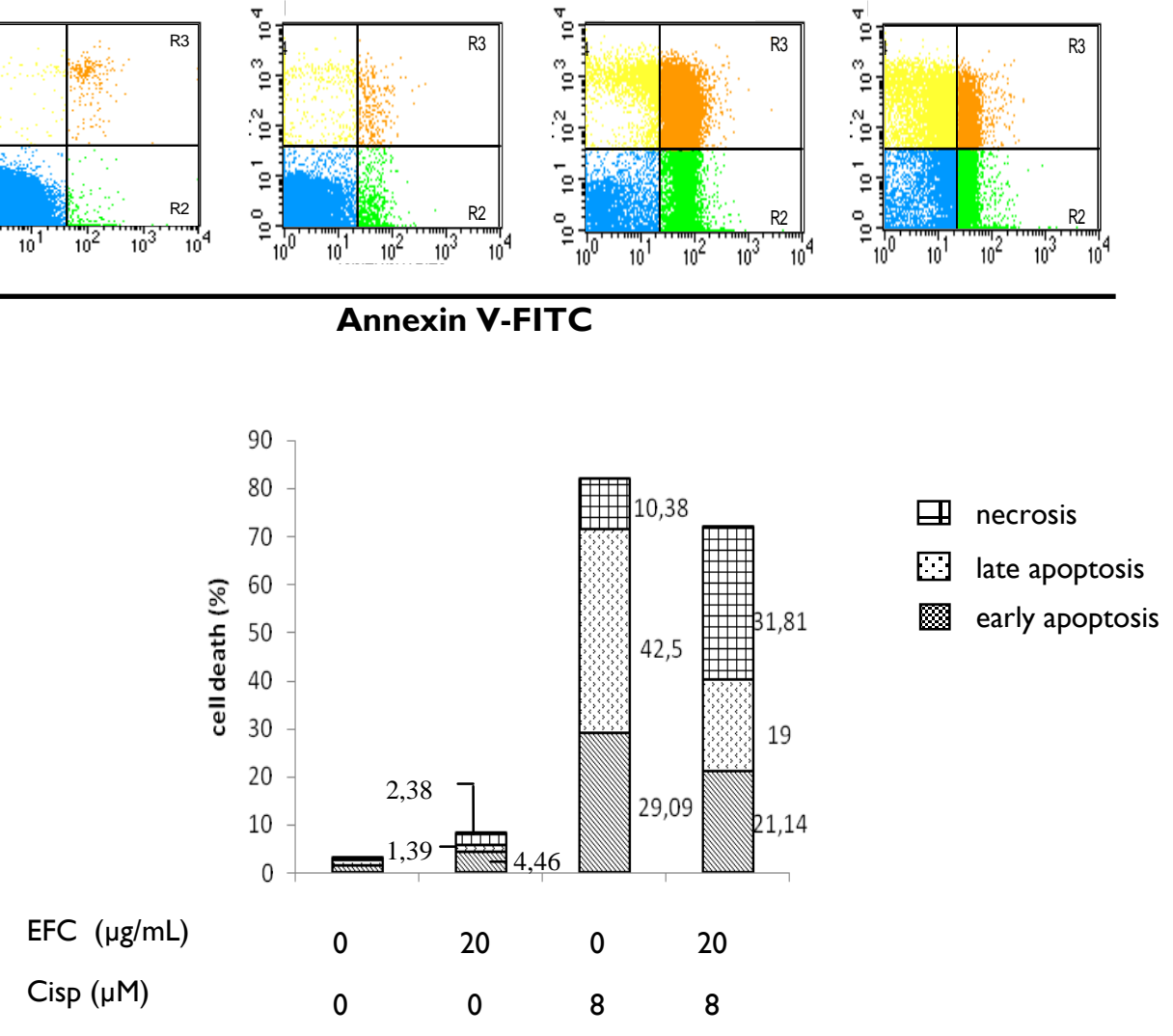

Annexin V-FITC

)

Figure 3. Cells death induction was caused by Cisp and its combination with EFC. (A) HeLa cells was treated with EFC $20 \mu \mathrm{g} / \mathrm{mL}$, Cisp $8 \mu \mathrm{M}$, and both of it for $24 \mathrm{~h}$. Then, Cells death was calculated by Flow cytometry assay using annexin V-FITC/PI staining. RI viable, R2 early apoptotic, R3 late apoptotic, R3 necrotic cells. (B) Data was analyzed using Microsoft exel 2007 describing cell death percentage.

\section{Effect of EFC and Cisp on Cell Cycle Modulation of HeLa Cells}

Cell Cycle analysis by flow cytometry was used to evaluate the cell cycle distribution by EFC, cisp and combination of both. Cisp has been reported to induce cell cycle arrest in G2/M phase in some cancer cells (Fehrmann and Laimins, 2003) and this study confirm that EFC induced cell cycle arrest in S phase. Cell distribution analysis was performed to investigate the effect of EFC addition to cisp on cell cycle arrest of HeLa cells. Fig. 4 shows HeLa cells treated with $28 \mu \mathrm{g} / \mathrm{mL}$ EFC, $8 \mu \mathrm{M}$ cisp, and a combination of the two agents for $24 \mathrm{~h}$. HeLa cells treated with EFC and cisp showed cells accumulation in $\mathrm{S}$ phase and $\mathrm{G} 2 / \mathrm{M}$ phase, respectively. While combination of both agents caused redistribution of the cell cycle in G1 and S phase compared to cisp-treated cells. In addition, accumulation of cells in $\mathrm{G} 2 / \mathrm{M}$ phase decreased compared to cisp-treated cells. These results above suggested that EFC enhances cytotoxicity induced by cisp on HeLa cells through cell cycle arrest in G1 and $\mathrm{S}$ phase. The cells progression in $\mathrm{G} 1$ and $\mathrm{S}$ phase might be caused by some proteins that play a role in cell cycle checkpoints. 

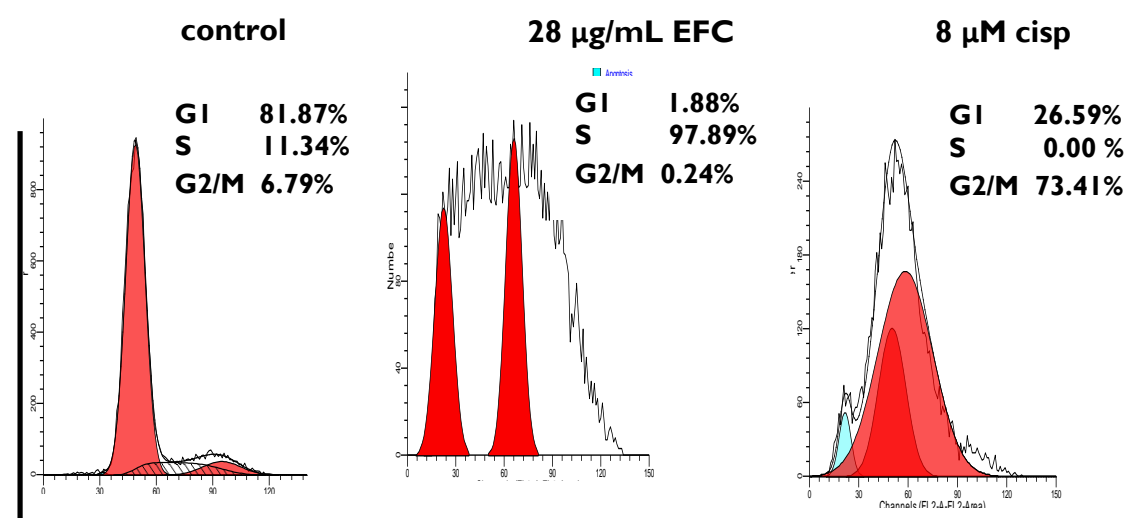

$28 \mu \mathrm{g} / \mathrm{mL}$ EFC + $8 \mu \mathrm{M}$ cisp

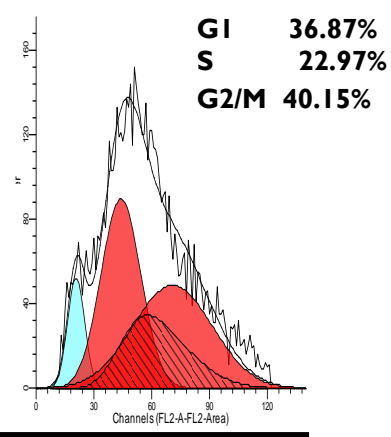

\section{DNA Content}

Figure 4. Cisp in combination with EFC caused cell cycle modulation on Hela cells. Cells were treated with 28 $\mu \mathrm{g} / \mathrm{mL}$ EFC, $8 \mu \mathrm{M}$ cisp and combination of both for $24 \mathrm{~h}$. Cell cycle distribution was calculated by Flow cytometry then analyzed using ModFit LT 3.0.

\section{Expression of p53 was caused by EFC and Cisp on HeLa Cells}

To confirm the mechanism of EFC and its combination with cisp in cell cycle arrest, therefore molecular target protein p53 was investigated. HeLa cells performed degradation and function loss of p53 as tumor suppressor protein which then cause uncontrolled proliferative cells (Fehrmann and Laimins, 2003; Minaguchi, et al., 1998). As shown in Fig. 5, immunocytochemistry evaluation indicated that p53 level increased significantly $(p<0.05)$ (Fig. $5 \mathrm{~A})$ confirmed by an intensive brown color in nucleus after being treated with $28 \mu \mathrm{g} / \mathrm{mL}$ EFCsingle treatment and in combination with $8 \mu \mathrm{M}$ cisp compared to cisp-single treatment and non-treated cells. The results suggest that EFC enhances cisp cytotoxicity on HeLa cells through p53 stabilization that perhaps play a role in cell cycle checkpoints.

(A)

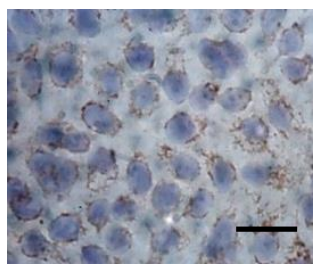

control

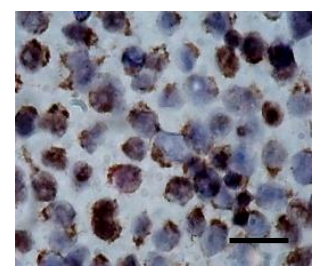

$28 \mu \mathrm{g} / \mathrm{mL}$ EFC

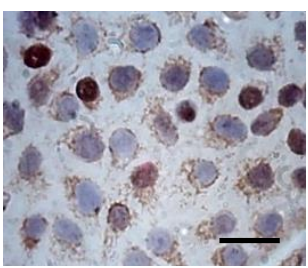

$8 \mu \mathrm{M}$ cisp

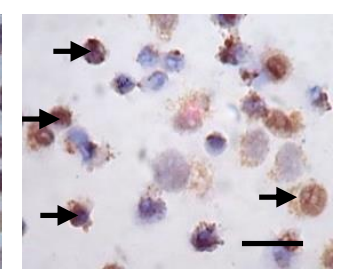

$28 \mu \mathrm{g} / \mathrm{mL}$ EFC + $8 \mu \mathrm{M}$ cisp

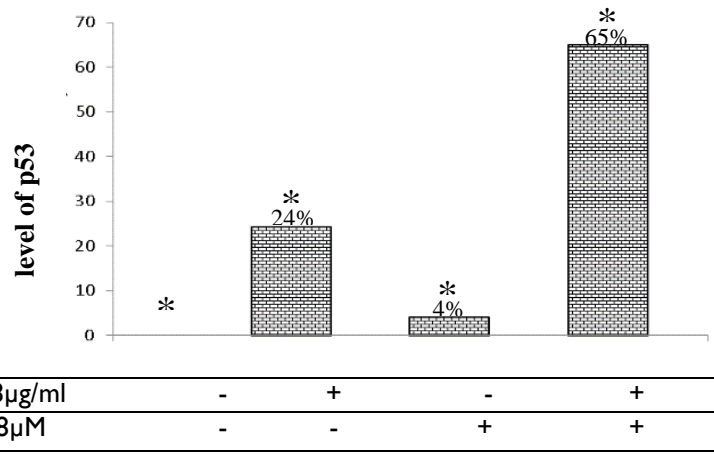

Figure 5. Effect of EFC and Cisp on p53 expression of HeLa cells. (A) HeLa cells were treated for $15 \mathrm{~h}$ with $28 \mu \mathrm{g} / \mathrm{mL}$ EFC, $8 \mu \mathrm{M}$ cisp, and in combination of both. Data was examined and photographed by binocular microscope. Bars: 5 $\mu M$ (magnification 400x). (B) Quantitative results showed analysis of p53 level in nucleus considered significantly different between combination treatment and single treatment $(p<0.05)$. 


\section{DISCUSSION}

Ethyl acetate fraction of $C$. sappan (EFC) performed more potent cytotoxic effect on $\mathrm{HeLa}$ cells compared to ethanolic extract $(320 \mu \mathrm{g} / \mathrm{mL}$, data not shown), showing a concentration dependent manner, with $\mathrm{IC}_{50}$ of $65 \pm 1.5 \mu \mathrm{g} / \mathrm{mL}$. Combination treatment of EFC and cisp at low concentration performed significant inhibition of cell viability compared to cisp-single treatment. A relatively low concentration was used to minimize the additional side effects and cellular resistance of cisp. Decreasing cells viability might be due to either cell death or cell cycle arrest.

This study shows that combination of EFC and cisp treatment on HeLa cells induced more necrotic rate up to $31.81 \%$ compared to cisp-single treatment. Afterward, EFC-single treatment caused less apoptosis compared to cisp. Hence, cisp is possibly more responsible in inducing apoptosis than EFC and its combination with EFC. The combination between EFC and cisp may affect on cell cycle modulation that can cause a decrease in cell viability on HeLa cells. Cisp has been reported as anti-cancer agent by inducing $\mathrm{G} 2 / \mathrm{M}$ phase arrest and apoptosis in some type of cancer cells (Jamieson and Lippard, 1999; Fehrmann and Laimins, 2003). Our results suggest that EFC enhanced HeLa cells' sensitivity to cisp through cell cycle redistribution, causing arrest in G1 and S phase. Cell cycle arrest is related to the efficacy of cytotoxicity of chemotherapeutic agent being used. Previous studies reported chemo-sensitization of cancer cells by many chemotherapeutic drugs perhaps due to cell cycle modulation (Lawrence, et al., 2003). Therefore, the delay of cell cycle distribution in G1 and S phase by EFC may be important in the sensitization of HeLa cells to cisp which causes a delay in G2/M phase. The experiments was continued to investigate the protein target on cell cycle by detecting the presence of p53.

HeLa cells are characterized with p53 degradation due to the binding of HPV E6 protein complexes to cellular factor E6AP which leads to ubiquitin-mediated degradation by proteasome (Buitrago-pérez, et al., 2009). EFC increased p53 expression in nucleus and its combination with cisp significantly increased p53 expression compared to EFC and cisp-single treatment (Fig. 5). The p53 protein activation may indirectly affect cellular response through some protein regulation causing cell cycle arrest to lead DNA repair or cell death activation (Jamieson and Lippard, 1999; Ricci and Zong, 2006; Schmitt, et al., 2002). These results suggested that the mechanism of EFC in sensitizing HeLa cells to cisp was possibly via p53-dependent. Brazilein as the main compound of $C$. sappan probably could inhibit HPV E6 interaction with E6binding protein E6AP. Therefore, brazilein may be amendable as HPV inhibitor agent and as competitor of vaccine to prevent the development of cervical cancer. However, this hypothesis still needs further investigation by in silico study.

\section{CONCLUSION}

In conclusion, EFC exhibits potential ability to enhance sensitivity of cervical cancer HeLa cells to cisp in vitro through cell cycle arrest with p53 stabilization. Further molecular target detection to investigate its cellular pathway needs to be conducted.

\section{ACKNOWLEDGEMENTS}

This study was partly supported by Grant from Hibah Penelitian Kerjasama Institusi, Universitas Gadjah Mada, Yogyakarta, Indonesia. We would like to especially thank to Prof. dr. Sofia Mubarika H., M. Med.Sc., Ph.D. (Faculty of Medicine) and Dr. Rarastoeti Pratiwi, M.Sc., Ph.D. (Faculty of Biology, Universitas Gadjah Mada) for the suggestion and correction.

\section{REFERENCES}

Badami, S. and Moorkoth, S., 2004, Caesalpinia Sappan-A Medicinal and Dye Yielding Plant, Nat. Prod. Rad., 3(2), 75-82.

Buitrago-Pérez, Á., Garaulet, G., Vázquez-Carballo, A., Paramio, J.M., 2009, Molecular Signature of HPV-induced Carcinogenesis : pRb , p53 and Gene Expression Profiling, Curr. Genomics, I 0(I), 26-34.

Castellsagué, X., 2008, Natural History and Epidemiology of HPV Infection and Ccervical Cancer, Gynecol. Oncol., I I 0(3), S4-S7. 
Cozmei, C., Scutaru, B., Constantinescu, D., Popa, D. and Carasevici, E., 2002, P53 Immunocytochemical Detection and Occupational Exposure to Atrazine, J. of Prevent. Medicine, I 0(3), 37-44.

Fehrmann, F. and Laimins L.A., 2003. Human Ppapillomaviruses : Targeting Differentiating Epithelial Cells for Malignant Transformation, Oncogene, 22(33), 520I-5207.

Forman, D., de Martel, C., Lacey, C.J., Soerjomataram, I., Lortet-Tieulent, J., Bruni, L., et al., 2012, Global Burden of Human Papillomavirus and Related Diseases, Vaccine, 30(5), FI2-F23.

Ho, JW., Leung, Y. and Chan, C., 2002, Herbal Medicine in the Treatment of Cancer, Curr. Med. Chem. Anticancer Agents, 2(2), 209-2I4.

Jamieson, E.R. and Lippard, S.J., 1999, Structure, Recognition, and Processing of CisplatinDNA Adducts, Chem. Rev., 99(9), 2467-2498.

Jemal, A., Bray, F., Center, M.M., Ferlay, J., Ward, E. and Forman, D., 20II, Global Cancer Statistics,. CA Cancer J. Clin., 6 I (2), 69-90.

Kim, D.S., Baek, N., Oh, S.R., Jung, K.Y., Lee, I. S. and Lee, H.K., 1997, NMR Assignment of Brazilein, Phytochemistry, 46(I), I77-I78.

Lawrence, T.S., Blackstock, A.W. and McGinn, C., 2003, The Mechanism of Action of Radiosensitization of Conventional Chemotherapeutic Agents, Semin. Radiat. Oncol., I3(I), I3-2I.

Leaver, D. and Labonte, G, 2010, HPV and Cervical Cancer, Radiation, 19, 27-44.

Lee, YM., Jeong, GS., Lim, HD., An, RB., Kim, YC. and Kim, EC., 2010, Isoliquiritigenin 2'-methyl Ether Induces Growth Inhibition and Apoptosis in Oral Cancer Cells Via Heme Oxygenase-I, Toxicol. in Vitro, 24(3), 776-782.

Martins, R.G., Parvathaneni, U., Bauman, J.E., Sharma, A.K., Raez, L.E., Papagikos, M.A., et al., 2013, Cisplatin and Radiotherapy with or without Erlotinib in Locally Advanced Squamous Cell Carcinoma of the Head and Neck: a Rrandomized Phase II Trial, J. Clin. Oncol., 3 I (I I), I4I5-I42I.

Meiyanto, E., Fitriasari, A., Hermawan, A., Junedi, S. and Susidarti, R.A., 20II, The Improvement of Doxorubicin Activity on Breast Cancer
Cell Lines by Tangeretin Through Cell Cycle Modulation, Orient. Pharm. Exp. Med., I I(3), 183-190.

Mosmann T., 1983, Rapid Colorimetric Assay for Cellular Growth and Survival: Application to Proliferation and Cytotoxicity Assays, J. Immunol. Methods, 65(I), 55-63.

Miller, R.P., Tadagavadi, R.K., Ramesh, G. and Reeves, W.B., 2010, Mechanisms of Cisplatin Nephrotoxicity, Toxins, 2(I I), 2490-25I8.

Minaguchi, T., Kanamori, Y., Matsushima, M., Yoshikawa, H., Taketani, Y. and Nakamura, Y., 1998, No Evidence of Correlation between Polymorphism at Codon 72 of p53 and Risk of Cervical Cancer in Japanese Patients with Human Papillomavirus 16/18 Infection, Cancer Res., 58(20), 4585-4586.

Mukherjea, D. and Rybak, L.P., 20II, Pharmacogenomics of Cisplatin-Induced Ototoxicity, Pharmacogenomics, I2(7), 10391050.

Prayong, P., Barusrux, S. and Weerapreeyakul, N, 2008, Cytotoxic Activity Sscreening of Some Indigenous Thai Plants, Fitoterapia, 79(7-8), 598-60I.

Rabik, C.A. and Dolan, M.E., 2007, Molecular Mechanisms of Resistance and Toxicity Associated with Platinating Agents, Cancer Treat. Rev., 33(I), 9-23.

Ren, L., Yang, X., Wang, G., Zhang, H., Zhao, L. and Mi, Z., 20II, Inhibition effect of brazilin to human bladder cancer cell line T24, World Acad. Sci. Eng. Technol., 5(I2), 657-66I.

Ricci, M.S. and Zong, W.X., 2006, Chemotherarapeutic Approaches for Targeting Cell Death Pathway, Oncologist, I I (4), 342-357.

Schmitt, C.A., Fridman, J.S., Yang, M., Lee, S., Baranov, E., Hoffman, R.M., et al., 2002, A Senescence Program Controlled by p53 and pl6INK4a Contributes to the Outcome of Cancer Therapy, Cell, I09(3), 335-346.

Sirichanchuen, B., Pengsuparp, T. and Chanvorachote, P., 2012, Long-term Cisplatin Exposure Impairs Autophagy and Causes Cisplatin Resistance in Human Lung Cancer Cells, Mol. Cell Biochem., 364(I-2), II-I8. 
Ueda, J-ya, Tezuka, Y., Banskota, A.H., Le Tran Q, Tran QK, Harimaya, et al., 2002, Antiproliferative Activity of Vietnamese Medicinal Plants, Biol. Pharm. Bull., 25(6), 75360.

Yen, C.T., Nakagawa-Goto, K., Hwang, T.L., Wu, P.C., Morris-Natschke, S.L., Lai, W.C., et al., 20II, Antitumor Agents. 27I:Total Synthesis and Evaluation of Brazilein and Analogs as Anti-inflammatory and Cytotoxic Agents, Bioorg. Med. Chem. Lett., 20(3), I037-1039.
Zhang, Y., Wang, C., Wang, H., Wang, K., Du, Y. and Zhang, J., 20II, Combination of Tetrandrine with Cisplatin Enhances Cytotoxicity Through Growth Suppression and Apoptosis in Ovarian Cancer in Vitro and in Vivo, Cancer Lett., 304(I), 2I-32.

Zhao, L., Wientjes, M.G. and Au, J.L., 2004, Evaluation of Combination Chemotherapy, Clin. Cancer Res., I 0(23), 7994-8004. 